African Crop Science Journal by African Crop Science Society is licensed under a Creative Commons Attribution 3.0 Uganda License. Based on a work at www.ajol.info/ and www.bioline.org.br/cs DOI: http://dx.doi.org/10.4314/acsj.v26i3.8

\title{
MOLECULAR CHARACTERISTICS OF Tomato mosaic virus INFECTING TOMATO IN UGANDA
}

\section{W. ARINAITWE, M. OCHWO-SSEMAKULA ${ }^{1}$, W.K. MBEWE ${ }^{2}$, P. SSERUWAGI ${ }^{3}$, S. KYAMANYWA ${ }^{1}$, M. ERBAUGH ${ }^{4}$, S. MILLER 5 and F. QU}

International Centre for Tropical Agriculture, P. O. Box 6247, Kampala, Uganda

${ }^{1}$ School of Agricultural Sciences, Makerere University, P. O. Box 7062, Kampala, Uganda

${ }^{2}$ Bvumbwe Agricultural Research Station, P. O. Box 5748, Limbe, Malawi

${ }^{3}$ Mikocheni Agricultural Research Institute, P. O. Box 6226, Dar es Salaam, Tanzania

${ }^{4}$ The Ohio State University, 113 Agricultural Administration Building 2120 Fyffe Road Columbus, OH 43210, USA

${ }^{5}$ The Ohio Agricultural Research and Development Centre, 1680 Madison Avenue, Wooster, OH 44691, USA

Corresponding author: mbewewillard@yahoo.co.uk, mknossemakula@caes.mak.ac.ug

(Received 6 March, 2018; accepted 20 August, 2018)

\begin{abstract}
Viral diseases are part of the limiting factors to tomato (Solanum lycopersicum L.) cultivation worldwide, reducing both the quality and quantity of yield. Tomato mosaic virus (ToMV) is one of the damaging viruses of tomato. This paper describes molecular characteristics of the full length genome of ToMV isolated from tomato in Uganda (ToMV-Ug). The genomic, ribonucleic acid (RNA), of this isolate is 6383 nucleotides (nts) in length, encoding four open reading frames (ORFs). Based on the homology with other ToMV strains, the 5' proximal 130 kilo dalton $(\mathrm{kDa}) \mathrm{ORF}$ and its read-through product $(180 \mathrm{kDa})$ are expected to encode two proteins required for viral genome replication; while the $30 \mathrm{kDa}$ middle ORF and the $17.5 \mathrm{kDa} 3$ ' proximal ORF are expected to encode the movement protein (MP) and coat protein (CP), respectively. The 5'- and 3'- untranslated regions (UTRs) are 71 and 201 nts, respectively. Comparison with previously published ToMV sequences showed that ToMV-Ug is $99 \%$ identical to ToMV strains from Africa (Egypt and Zimbabwe), as well as diverse locations such as China, Australia, Germany and Japan; suggesting high levels of sequence conservation within this virus. This is the first report detailing molecular analysis of a ToMV isolate from Uganda and the Eastern and Central Africa regions.
\end{abstract}

Key Words: Ribonucleic acid, Solanum lycopersicum, Tobamovirus

\section{RÉSUMÉ}

Les maladies virales font partie des facteurs limitant la production mondiale de la tomate (Solanum lycopersicum L.), réduisant à la fois la quantité et la qualité du rendement. Le virus de la mosaïque de la tomate (ToMV) est l'un des virus endommageant la tomate. Ce papier décrit les caractéristiques moléculaires de la longueur du génome de l'isolat ToMV de la tomate en Ouganda (ToMV-Ug). L'acide génomique, ribonucléique (ARN), de l'isolat a une longueur de 6383 nucléotides (nts), codant quatre cadres de lecture ouverts (ORFs). Sur la base de l'homologie avec les autres souches de ToMV, le proximal 5' de 130 kilo dalton ( $\mathrm{kDa})$ de l'ORF et sa lecture à travers le produit $(180 \mathrm{kDa})$ sont espérés coder pour deux protéines nécessaires à la réplication du génome viral ; alors que les 30 kDa du ORF moyen et les 17,5 kDa du proximal 3' du ORF sont espérés coder pour le mouvement de la protéine (MP) et la protéine de l'enveloppe (CP), respectivement. Les régions non traduites du 5' et 3' (UTRs) sont de 
71 et 201 nts, respectivement. La comparaison avec les séquences (ToMV) précédemment publiées a montré que ToMV-Ug est à $99 \%$ identique aux souches ToM de l'Afrique (Egypte et Zimbabwé), ainsi que diverses localités telles que la Chine, l'Australie, la Germanie et le Japon ; suggérant de hauts niveaux de séquence de conservation dans ce virus. Ceci est le premier rapport détaillant l'analyse moléculaire d'un isolat ToMV d'Ouganda et les régions Est et Centre de l'Afrique.

Mots Clés: Acide ribonucleic, Solanum lycopersicum, virus du Tobamo

\section{INTRODUCTION}

Tomato mosaic virus (ToMV) is among the most important viruses of tomato worldwide (Hanssen et al., 2010). It is also the most resilient virus in terms of ability to survive outside plant cells and in dead tissues (Lanter et al., 1982). The virus is a member of the Tobamovirus genus. It is mechanically transmitted, with a very wide host range including, more than 150 species of vegetables, flowers and weeds (Hanssen et al., 1990; Ismaeil et al., 2012). The blend of its extreme survival ability and mechanical transmission makes its management a nightmare among most tomato growers worldwide. Management is even worse in the developing world where access to clean resistant tomato varieties is limited.

In Africa, literature on ToMV is scanty, with the first report of severe viral damage among East African vegetable growers being in the early 1990s (Brunt et al., 1997). In Uganda, the occurrence of ToMV was first established in the late 1990s (Ssekyewa, 2006), then estimated to cause up to $100 \%$ yield losses. Recently, more than $60 \%$ incidence of ToMV was observed in field samples, with high levels of mixed virus infections (Arinaitwe, 2013). However, all these findings have been based on field symptom expression in Uganda (Goelet et al., 1982; Klug, 1999;Arinaitwe, 2013) and antibody-based methods, which are at times reported as misleading (Ssekyewa, 2006). This is because of relatedness in symptom expression among many plant viruses and cross reactivity at serology level (López et al., 2009).

López et al. (2009) indicated that successful management of many plant viruses largely requires real-time detection and identification. To this effect, molecular-based detection and identification methods such as the polymerase chain reaction (PCR) and genome sequencing have been reported to be more informative in the crafting of durable management options for many viruses, including ToMV. Such techniques help in uncovering novel plant pathogens, and have been used in many crops (Deusdedith, 2011) and diagnostics for tomato infecting viruses (Chen et al., 2011; López-Gresa et al., 2012; Panno et al., 2012; Andolfo et al., 2014). Knowledge of the molecular composition of plant viruses is critical for development of diagnostics, and consequently facilitates management of such viruses.

This study was, therefore, executed to detect ToMV in major tomato growing districts of Uganda using PCR based techniques, and determine the identity and molecular characteristics of ToMV by sequencing its complete genome. This is the first ever complete genome of ToMV isolated from Uganda. Sequence knowledge generated in this study will, therefore, help in development of diagnostic tools for management of ToMV in Uganda.

\section{MATERIALS AND METHODS}

Source of virus isolates. Tomato leaf samples used in this study were collected from farmers' fields in eight major tomato growing districts (Fig. 1). The districts included Kasese (Zone VII), Mbarara (VIII-East / IXWest), Rukungiri and Ntungamo (IX) in western Uganda; Mpigi (VI) and Luwero (VIII) in central Uganda, Kamuli (V) and Mbale (X) in eastern Uganda. The climatic 


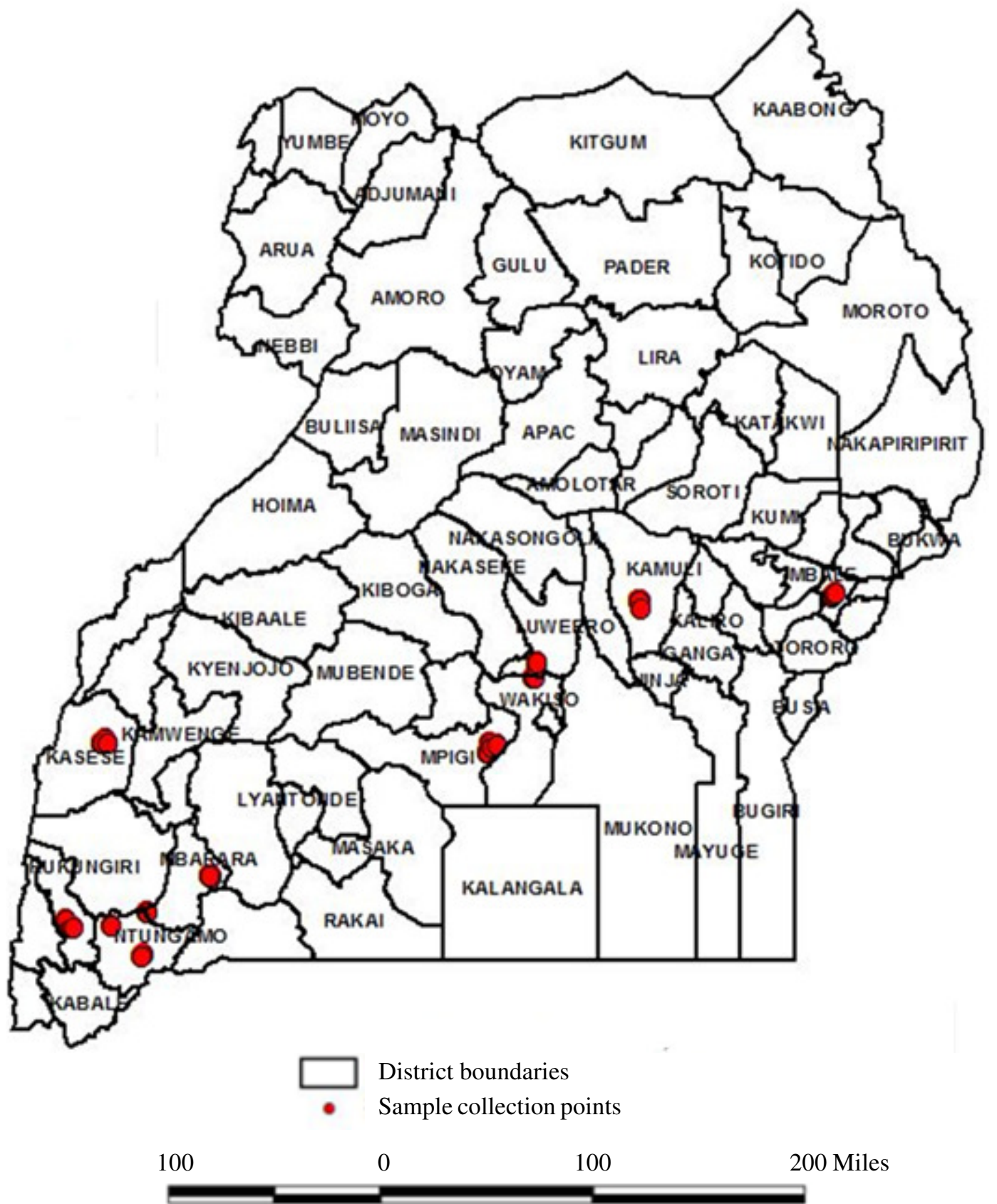

Figure 1. Map of Uganda showing field locations for samples used in RT-PCR. 
conditions of these areas are those described in Ssekyewa (2006). A total of 69 fresh leaf samples, confirmed positive for ToMV or Tobacco mosaic virus (TMV) infections by enzyme linked immunosorbent assays (ELISA), were preserved by lyophilisation and with the RNA stable reagent (Biomatrica, Inc., San Diego, California, USA). They were then shipped and analysed at the Ohio Agricultural Research and Development Center (OARDC, Wooster, Ohio, USA). At OARDC, each lyophilised sample was ground in $2 \mathrm{ml}$ of inoculation buffer $(10 \mathrm{mM}$ sodium phosphate buffer, $1 \%$ celite, and $\mathrm{pH} 7.0$ ), and used to mechanically inoculate four young tomato plants of the "Peto" variety (Tiberini et al., 2010). The inoculated plants were reared in a greenhouse, and systemically-infected foliar tissue harvested at 14 days post inoculation for total RNA isolation.

Isolation of total RNA. Total RNA was extracted from infected tomato leaves using the Trizol reagent (Invitrogen, Carlsbad, California, USA), following the manufacturer's instructions. Briefly, $0.3 \mathrm{~g}$ of leaf sample was ground to powder in liquid nitrogen using a mortar and a pestle, and homogenised in $1 \mathrm{ml}$ Trizol reagent. The homogenate was then transferred to a $2 \mathrm{ml}$ eppendorf tube and incubated at room temperature for 5 minutes $(\mathrm{min})$, to permit complete dissociation of nucleoprotein complexes. Three hundred microliters (300 il) of cold chloroform was then added; followed by thorough mixing and the tube was then centrifuged at $12,000 \mathrm{rpm}$ for $15 \mathrm{~min}$ at $4^{\circ} \mathrm{C}$.

The aqueous phase that contained RNA was decanted into a sterile eppendorf tube and the RNA was precipitated with isopropanol. The RNA pellet was then washed with $1 \mathrm{ml}$ $75 \%$ ethanol, and dissolved in 100 il RNasefree water. The concentration of extracted nucleic acid was determined using a Nano Drop ND-1000 photo spectrometer (Nano Drop Technologies Inc., Wilmington, Delaware, USA). The integrity of RNA was also confirmed by agarose gel electrophoresis. Total RNA samples prepared in the Biotechnology Laboratory at the School of Agricultural Sciences, Makerere University, Uganda and preserved in RNAstable ${ }^{\text {(Sigma }}$ Aldrich, Missouri, USA) was reconstituted by addition of $25 \mu \mathrm{l}$ of RNase-free water.

Amplification of viral RNA. Six pairs of primers were used to amplify ToMV complementary deoxyribonucleic acid (cDNA) with reverse transcriptase polymerase chain reaction (RT-PCR) (Table 1). Five of the six primer pairs were designed based on the sequences of a previous ToMV isolate (GenBank accession FN985165). The sixth pair of primers was derived from Letschert et al. (2002).

A two-step RT-PCR procedure was used to amplify the full length of ToMV. In the first step, cDNA was synthesized by mixing 5.75 $\mathrm{ml}$ DNase-treated total RNA; $2 \mathrm{ml}$ dNTP mix (10 mM dATP, dCTP, dGTP, and dTTP); $1 \mu \mathrm{l}$ of $20 \mathrm{mM}$ reverse primer, and $2.25 \mathrm{ml}$ RNasefree water in a $0.5 \mathrm{ml}$ tube. The tube was then incubated at $65{ }^{\circ} \mathrm{C}$ for $5 \mathrm{~min}$, chilled on ice, before adding $2 \mathrm{ml}$ of reverse transcriptase enzyme mix (Clontech, Palo Alto, California, USA) and $6 \mathrm{ml}$ RNase-free water. The tube was then incubated at $25^{\circ} \mathrm{C}$ for $10 \mathrm{~min}, 40^{\circ} \mathrm{C}$ for $30 \mathrm{~min}$, and $85{ }^{\circ} \mathrm{C}$ for $5 \mathrm{~min}$. The synthesized cDNA was diluted $1: 4$ with $\mathrm{ddH}_{2} \mathrm{O}$ and stored at $-20{ }^{\circ} \mathrm{C}$ for future use.

In the second step, a PCR reaction consisting of $4 \mathrm{ml} \mathrm{cDNA} ; 10 \mathrm{ml}$ of $2 \mathrm{x}$ EconoTaq plus green master mix (Lucigen Corporation, Middleton, Wisconsin, USA); 2 $\mathrm{ml}$ of $10 \mathrm{mM}$ of each primer (forward and

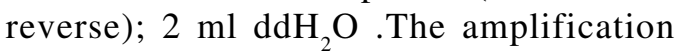
conditions included an initial denaturation step at $94{ }^{\circ} \mathrm{C}$ for $2 \mathrm{~min}$, followed by 40 cycles of $94{ }^{\circ} \mathrm{C}$ for 30 seconds (denaturation), $58{ }^{\circ} \mathrm{C}$ for $30 \mathrm{~s}$ (annealing), $72{ }^{\circ} \mathrm{C}$ for $2 \mathrm{~min}$ (extension); and a final extension at $72{ }^{\circ} \mathrm{C}$ for 6 min.

All PCR reactions were performed in a PTC-100 thermocycler (MJ Research Inc., 
TABLE 1. Primers used in amplification of ToMV isolated from tomato in Uganda

\begin{tabular}{|c|c|c|c|c|}
\hline Primer name & Primer sequence $\left(5^{\prime}-3^{\prime}\right)$ & Region & Size & Reference \\
\hline ToMVspecR & CGG AAG GCC TAA ACC AAA AAG & Coat protein & 672 & Letschert et al., 2002 \\
\hline Tob-Uni1F & ATTTAAGTGGASGGAAAAVCACT & & & \\
\hline T7-ToMV-W-1F & $\begin{array}{l}\text { GGG AAA TAA TAC GAC TCA CTA TAG TAT TTT } \\
\text { TAC AAC AAT TAC }\end{array}$ & Methyltransferase & 627 & This study \\
\hline ToMV-W-627R: & ACG TTT GGA AAG TAT CGT GAC AGA & & & \\
\hline ToMV-W-633F & GCA TTC TCA AGA ATG TTA CAC GGG AA & Methyltransferase & 1811 & This study \\
\hline ToMV-W-2444R: & CCA GTT ATC GCA CGT AAT AAT GCC AA & & & \\
\hline ToMV-W-2326F: & GGC TAG TTA AAC CAT CCG CAA AGA AC & Replicase and movement protein & 3434 & This study \\
\hline ToMV-W-5760R: & CAG CCC ATA CAG ATG ACA AAA ACA CA & & & \\
\hline ToMV-6003F & GCA GAG TCC GAC AAC AGC TGA AA & Coat protein & 450 & This study \\
\hline rolC-ToMV-W-6383R & GCA TAA AGG TCG AAT GGG CC & & & \\
\hline ToMV-6174F & GCA TCT TAA ATG CAT AGG TGC TGA A & Coat Protein & 380 & This study \\
\hline
\end{tabular}


Waltham, Massachusetts, USA). Amplicons were analysed in $1.2 \%$ agarose gel in Trisacetate-EDTA buffer. Gels were stained with ethidium bromide and DNA was visualised with UV light.

Cloning and sequencing. Amplicons were purified using a DNA Clean and Concentrator $^{\mathrm{TM}}-5$ kit (Zymo, Irvine, California, USA), following the manufacturer's protocol and subsequently cloned into a pGEM-T Easy vector following the recommended protocol (Promega, Madison, Wisconsin, USA). The resulting plasmids were purified using a Zymo kit (Irvine, California, and USA) and $2 \mathrm{ml}$ of each plasmid prep digested with EcoRI before sequencing. For direct PCR product sequencing, fragments were cleaned using a Zymo PCR clean-up kit and sequenced from both ends. Sequencing was done with the ABI $3100 X 1$ sequencer at the Molecular and Cellular Imaging Center at OARDC in Wooster, USA. The resulting annotated full genome sequence was deposited in the GenBank under the accession number MG456601.

Sequence and phylogenetic analysis. A total of 34 other full genome sequences of tobamoviruses were downloaded from NCBI (https://www.ncbi.nlm.nih.gov/) and analysed together with the newly sequenced Ugandan isolate. Sequence alignment and percentage nucleotide identities were computed in Geneious Software v10.0.5 (Kearse et al., 2012). Recombination events were detected using nine recombination detection programs within the RDP4 package (http:// darwin.uvigo.es/rdp/rdp.html) namely: RDP, GENECONV, MaxChi, Chimaera, Bootscan, Siscan, PhylPor, LARD, and 3Seq (Martin et al., 2015). Analyses were carried out using default settings (except sequences were set to linear) and the Bonferroni correction P-value cut-off of 0.05 . Only breakpoints supported by at least three methods were considered putative (Posada, 2002). The sequences were aligned using ClustalW (Larkin et al., 2007) in MEGA 7 (Kumar et al., 2016) and edited manually. The alignment was trimmed to give all sequences uniform length. The evolutionary history was inferred by using the Maximum Likelihood statistical method based on the best fitting nucleotide substitution model (General Time Reversible), (Nei and Kumar 2000). Initial tree(s) for the heuristic search were obtained automatically by applying NeighborJoin and BioNJ algorithms to a matrix of pairwise distances estimated using the Maximum Composite Likelihood approach, and then selecting the topology with superior log likelihood value. All computational analyses were conducted in MEGA7 (Kumar et al., 2016).

\section{RESULTS}

RT-PCR-based confirmation of ToMV identity. The presence of ToMV was confirmed by PCR in most of the tomato samples exhibiting typical symptoms of viral diseases, including mosaic and curly leaves, mottling of young leaves, leaf chlorosis, crinkling, flower abscission, necrosis, dieback, no fruit formation, yellow mosaic and bronzing, stunting, vein banding and clearing. The locations of the fields from which the samples were collected are denoted as red dots in Figure 1. ToMV presence in the samples was shown by the detection of a PCR fragment of expected size (672 bp) (Fig. 2). Positive samples were 74\% (51/69) of the total field samples analysed. ToMV was detected in all districts surveyed, even in Mbale where no ToMV was detected with ELISA. Overall, Kasese had the highest incidence (92\%), followed by Rukungiri (83\%), Ntungamo (80\%), Luwero (75\%), Mbarara and Mpigi (73\%), Mbale $(67 \%)$ and Kamuli (33\%). Generally, incidence of ToMV based on PCR was above $60 \%$ in most districts, except Kamuli district.

Sequence and phylogenetic analysis. By combining the sequences of five overlapping PCR fragments (Fig. 3), the full length sequence of ToMV-Ug was obtained (Fig. 4). 


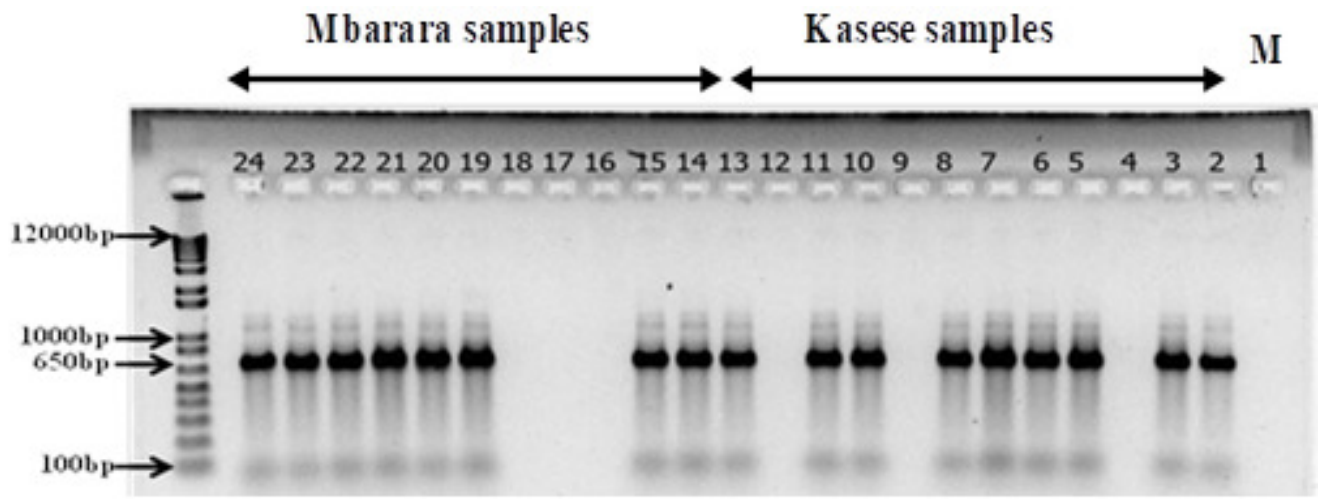

Figure 2. Gel electrophoresis. Image showing results of RT-PCR detection of ToMV in a selected subset of field samples. Lane 1 represents a sample isolated from a healthy plant serving as the negative control (M); Lanes 224 show the presence the ToMV-specific RT-PCR products in most reactions that used the field samples as templates.

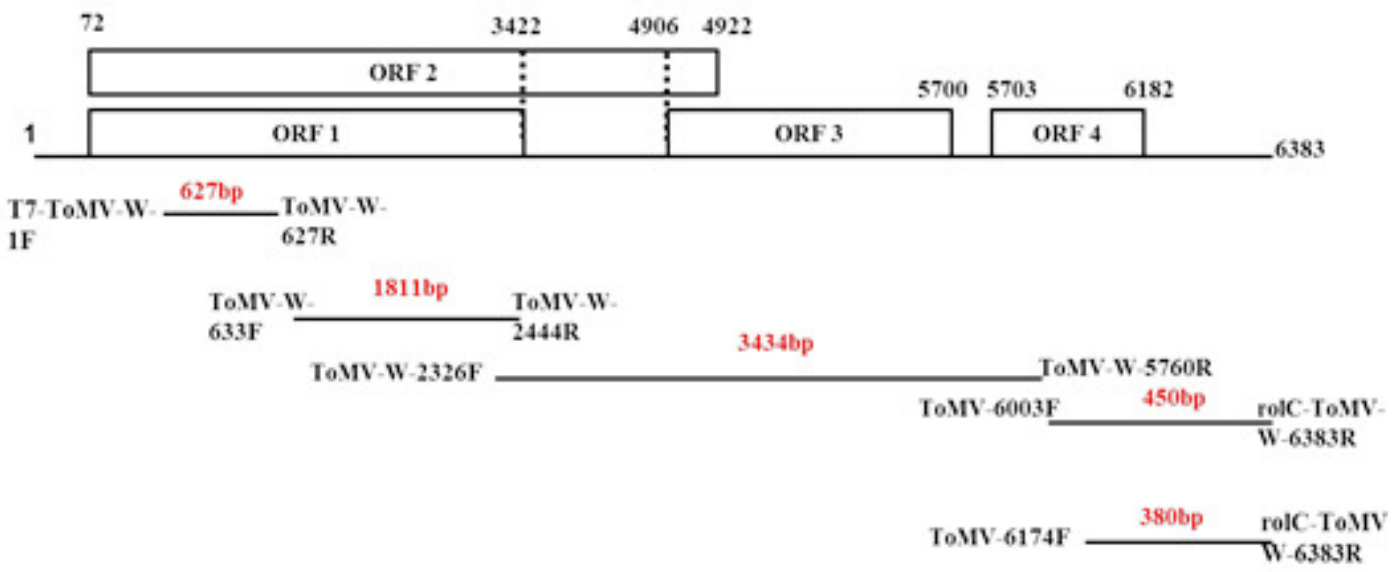

Figure 3. Methodological graphical representation showing how the full length of ToMV- Uganda was assembled.

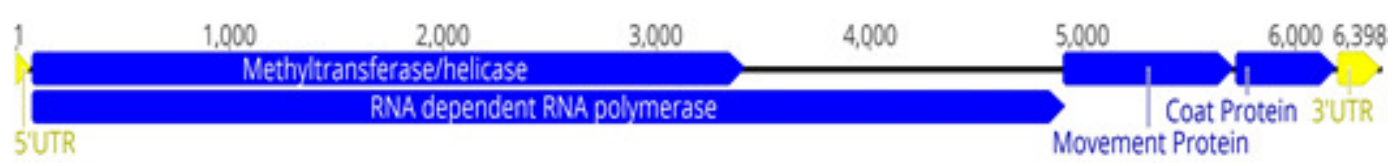

Figure 4. Genetic map showing composition of full length ToMV genome with respective annotated genes. The numbers represent nucleotide bases, while the blue coloured shows putative coding genes. The 5'UTR and 3'UTR are at the ends. 
The sequence of T7-ToMV-W-1F used as a forward primer for amplifying the 5' terminal fragment, was derived from the sequences of other known ToMV isolates, which share a $19 \mathrm{nt}$ highly conserved region, at their 5'termini. The 3' UTR sequence, which had only six conserved nucleotides (GGCCA) was obtained with two pairs of nested primers (ToMV-6003F and rolC-ToMV-W-6383R; ToMV-6174F and rolC-ToMV-W-6383R) that amplified two overlapping fragments (450 and $380 \mathrm{bp}$ ) respectively. These fragments were sequenced, and the derived sequences were assembled into the full length sequence.

The resultant complete sequence of ToMVUganda, after assembling different sequences of overlapping PCR products, was $6383 \mathrm{nt}$ long with four ORFs. The first open reading frame (ORF-1) was 3351 nucleotides long, starting at nucleotide 72 and ending at nucleotide 3422 ; in effect encoding 1,116 amino acids (aa). The second ORF formed as a result of ORF-1 read-through (AUG) extended translation ended at the nucleotide position 4922. This ORF was 4851 nucleotides long, coding for 1616 aa. The third ORF (ORF-3) covered nucleotide bases 4906 to 5700 , with a total of 795 nucleotides and coding for 364 aa. The last frame (ORF-4) was 480 nucleotides long, from nucleotide positions 5703 to 6182 , encoding 159 aa. The $5^{\prime}$ and $3^{\prime}$ ends were 71 and 201 nucleotides long, respectively, with no known amino acids (Fig. 3).

In ORF-1, amino acid percentage identity ranged from $16 \%-99 \%$. Like in the $180 \mathrm{kDa}$ ORF, amino acid sequences for isolates from tomato were $99 \%$ identical while those from other crops ranged from $16 \%-91 \%$. In ORF2 , amino acid percentage identity to other tobamoviruses ranges from $64 \%$ - 99\%. Amino acid sequences for species isolated from tomato were $99 \%$ identical while those from other crops such as broad beans, petunia, pepper and crucifers were between $64 \%$ and $91 \%$ (Table 2). In ORF-3, amino acid identity was in the range of $38 \%-100 \%$. Those compared from tomato had their identity range between $76 \%$ and $100 \%$ while those from other crops ranged between $38 \%$ and $76 \%$. Amino acid sequences for ToMV-Uganda were $100 \%$ identical to ToMV 11A from Fukushima, Japan, TMV-K and - L strains from Russia and China, respectively. In ORF-4, amino acid identity ranged between $48 \%$ and $100 \%$. Comparison of ToMV-Ug with those isolated from tomato showed a similarity range of $96 \%$ - $100 \%$ - and $48 \%$ - $83 \%$ with isolates from other crops (petunia, broad bean, pepper, rib grass and crucifers) (Table 2). Generally, on the basis of comparison of ORFs 1 - 4, ToMVUganda was $100 \%$ identical to ToMV strains isolated from Australia, China, Japan and the TMV-L strain from China.

Comparison of the full length of the ToMV$\mathrm{Ug}$ isolate with other isolates in the GenBank revealed $99 \%$ amino acid similarity with ToMV isolates from Germany, China, Japan and Australia, and the TMV-L strain from China (Table 2). Only 9\% identity was realised with tobamoviruses that infect crucifers. Phylogenetic analyses placed the newly sequenced ToMV-Uganda in close relationship with ToMV isolates from China, Japan and Australia. Furthermore, the monophyletic clade of ToMV with $99 \%$ bootstrap support shared closer relationship with Tomato mild mottle virus another tobamovirus (Fig. 5).

\section{DISCUSSION}

Detection of Tomato mosaic virus in

Uganda. The polymerase chain reaction was thus used in this study to confirm the identity of and characterise ToMV infecting tomato in Uganda. Much higher incidences of the virus were observed with PCR, even in districts where ELISA results were negative. This could be attributed to latent infections or low titres that sometimes occur with viral disease infection (Biosca et al., 2006). In addition, previous reports show that commercially available serology-based kits for most economically important pathogens are not suitable for analysing latent infections as they usually have relatively low sensitivity and do 
TABLE 2. Percentage identity of ToMV-Uganda with other sequenced tobamoviruses

\begin{tabular}{|c|c|c|c|c|c|c|c|c|}
\hline \multirow[t]{2}{*}{ Accession no. } & \multirow[t]{2}{*}{ Virus name } & \multirow[t]{2}{*}{ Source } & \multicolumn{6}{|c|}{ Amino acid identity (\%) } \\
\hline & & & Host & $180 \mathrm{kDa}$ & $130 \mathrm{kDa}$ & $30 \mathrm{kDa}$ & $17.5 \mathrm{kDa}$ & Full length \\
\hline AF332868 & Tomato mosaic virus isolate Queensland & Australia & Tomato & 99 & 99 & 99 & 100 & 99 \\
\hline GQ280794 & Tomato mosaic virus strain N5 & China & Tomato & 99 & 99 & 99 & 96 & 99 \\
\hline AJ132845 & Tomato mosaic virus & China & Tomato & 99 & 99 & 99 & 100 & 99 \\
\hline AJ417701 & Tomato mosaic virus Camellia strain & China & Tomato & 99 & 98 & 99 & 98 & 98 \\
\hline AB083196 & Tomato mosaic virus L11A-Fukushima & Japan & Tomato & 99 & 99 & 100 & 100 & 99 \\
\hline DQ873692 & Tomato mosaic virus strain $1-2$ & Germany & Tomato & 99 & 99 & 99 & 98 & 99 \\
\hline FN985165 & Tomato mosaic virus - China & China & Tomato & 99 & 99 & 99 & 100 & 99 \\
\hline AJ011933 & Tobacco mosaic virus strain IM & China & Broad bean & 91 & 90 & 76 & 83 & 85 \\
\hline Z92909 & Tobacco mosaic virus $\mathrm{K}$ strain & Russia & Tomato & 99 & 99 & 100 & 96 & 93 \\
\hline AF155507 & Tobacco mosaic virus & China & Tomato & 98 & 98 & 91 & 96 & 85 \\
\hline EF392659 & Tobacco mosaic virus pet-TW & Taiwan & Petunia & 91 & 91 & 80 & 83 & 85 \\
\hline AF165190 & Tobacco mosaic virus & China & Tomato & 91 & 91 & 76 & 83 & 49 \\
\hline X02144 & Tobacco mosaic virus L strain & China & Tomato & 99 & 99 & 100 & 100 & 99 \\
\hline D63809 & Tobacco mosaic virus & Japan & Rakkyo & 90 & 90 & 76 & 81 & 84 \\
\hline DQ355023 & Bell pepper mottle tobamovirus & S. Korea & Pepper & 87 & 88 & 69 & 81 & 35 \\
\hline AB276030 & Pepper mild mottle virus strain L4BV & Japan & Capsicum & 76 & 18 & 63 & 71 & 19 \\
\hline DQ223770 & Ribgrass mosaic virus isolate Impatiens & Germany & Impatiens & 76 & 16 & 37 & 48 & 19 \\
\hline AY318866 & Crucifer tobamovirus & Britain & Crucifers & 64 & 16 & 38 & 48 & 9 \\
\hline
\end{tabular}




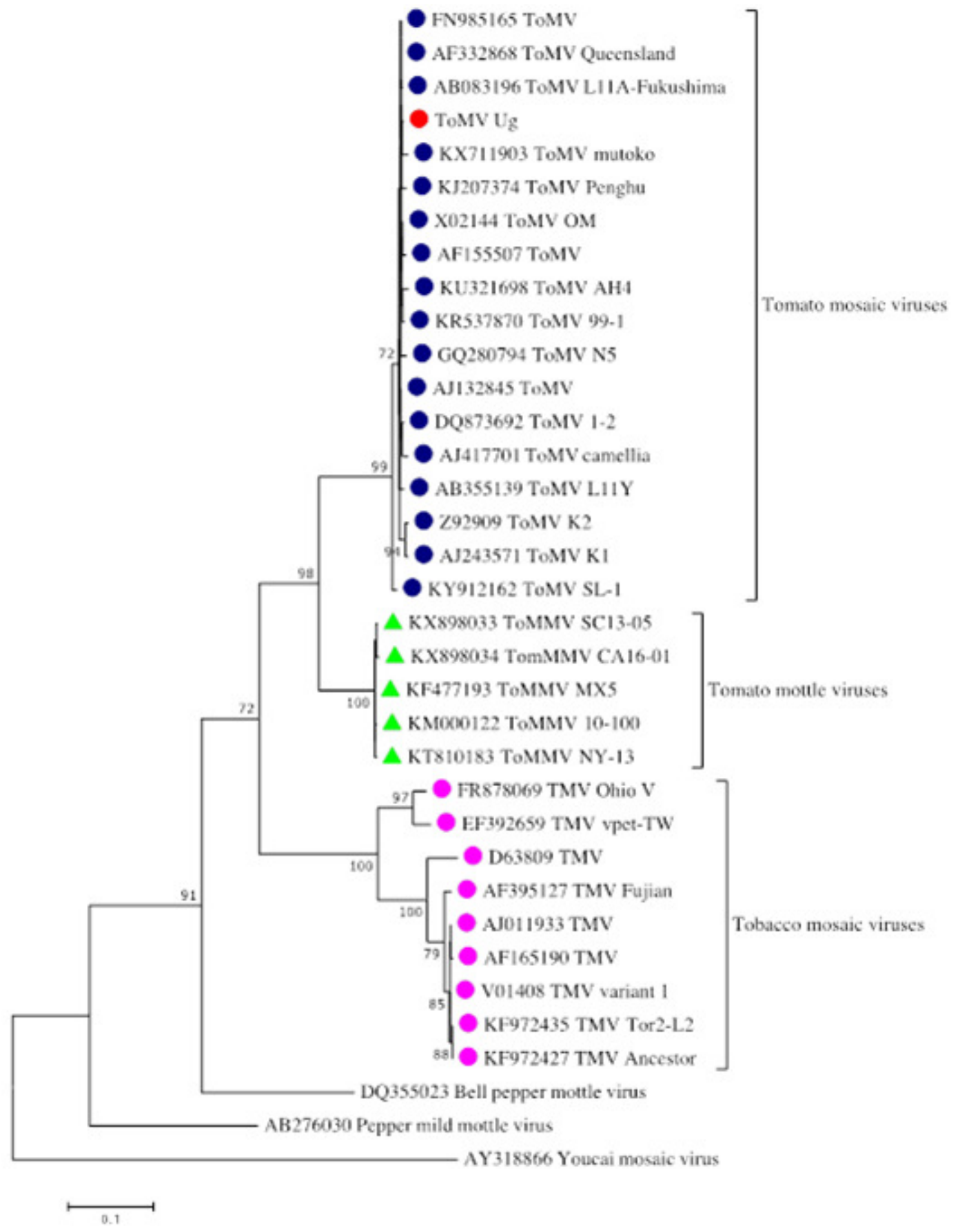

Figure 5. A maximum likelihood dendogram showing phylogenetic relationship between ToMV-Ug with other representative ToMV isolates as well positioning of ToMV with other tobamoviruses. Only bootstrap values higher than $70 \%$ are shown. The scale is in substitutions/site. 
not detect low titres of the target pathogen in asymptomatic tissues (López et al., 2009). Successful PCR amplification of ToMVUganda with the TobUnil/ToMVspec (Letschert et al., 2002) suggests possible genomic similarities with the China strain whose coat protein gene was used in the primer design. However, differentiation of the genus Tobamovirus based on the coat protein gene has been reported as misleading since ToMV uses all its four proteins in infection (Hanssen et al., 2010). Nevertheless, reproduction of a similar result with Letschert et al., (Letschert et al., 2002) indicated that the primer pair (TobUni1/TobUni1/ToMVspec) can be reliably used in subsequent rapid diagnosis of ToMV in Uganda. After all, most biological and serological assays used in identification of tobamovirus species are reportedly time consuming and laborious and at times lead to ambiguous results (Letschert et al., 2002). In summary, considering the high prevalence of ToMV, even in mixed infections (Ssekyewa, 2006), this primer could play a pivotal role in future epidemiological studies on tomato viruses in Uganda.

Nucleotide identity and genome structure of ToMV-Uganda isolate. The complete nucleotide sequence of ToMV-Uganda was also determined. Sequence analysis clearly confirmed ToMV-Ug as a tobamovirus with four major ORFs in the genomic RNA (gRNA). The sequence had a -TAG- stop codon at position 3422 that marked the end of the methyltransferase protein, which was subsequently suppressed to form the RNA dependent RNA polymerase protein. At position 3423 - 3428, it had a-CAATTA- motif that is normally recognised by the GUA anti-codon, which leads to the intermittent production of the180-kDa protein (Fillmer et al., 2015).The $30 \mathrm{kDa}$ movement protein and the $17.5 \mathrm{~K}$ coat protein were separated by -AT- at positions 5700 - 5703. All these characteristics are common among tobamoviruses (King et al., 2012; Ismaeil et al., 2012; Fillmer et al., 2015).
The ToMV-Uganda sequence was also 6.3 kilo bases $(\mathrm{kb})$ in length and fell within the 6.3 to $6.6 \mathrm{~kb}$ range for most tobamovirus genomes (Chen et al., 2011; Panno et al., 2012; Fillmer et al., 2015; Sui et al., 2017). Moreover, the Ugandan strain of ToMV was positive-sense and single-stranded, which concurred with previous descriptions of the genomic structure for ToMV strains from USA and China (Goelet et al., 1982; Klug, 1999).

\section{Evolutionary phylogenetic relationship of} ToMV-Uganda with other known strains. Phylogenetic comparisons of full genome sequences showed closest relationship of ToMV-Uganda to strains from China (accessions AJ132845, FN985165; 99\%), Japan (accession AB083196; 99\%) and Germany (accession DQ873692; 99\%); while distant relation occurred with the Australian isolate (AF332868; 84\%). Aguilar et al. (1996) suggested that tobamoviruses, which are $95 \%$ or higher in nucleotide identity, should be considered strains of the same virus while those that are $80-95 \%$ identical would be closely related viruses. Tobamoviruses that are $60-79 \%$ identical would then be considered different virus species. The Ugandan isolate of ToMV can, therefore, be considered a strain closely related to strains of ToMV from Japan, China, Australia and Germany (Fig. 5). This finding could provide insights on studies on migration of the virus species worldwide.

Coat protein amino acid comparison alone revealed 100\% homology of ToMV-Ug with the China strains (accessions FN985165 and X02144), Japan strains (AB083196) and Queensland strain (AF332868). This shows that the CP amino acid is highly conserved implying that resistance sources found in one of those countries can serve across all the other regions with similar homology. This is key in disease management and surveillance as resistance sources found in one of those countries can serve across all the other regions with similar homology. In the past, most comparisons were based on coat protein identity (Hanssen et al., 2010). While this may 
be merely speculative, close resemblance of ToMV-Uganda with these isolates in the CP region might suggest a likelihood of the Ugandan strain having evolved from those in the Asian, European and Australian continents. If proven, this finding would have implications for future disease surveillance. It should be noted that climatic conditions such as temperature, relative humidity, rainfall and wind speed are considered as the most important factors that favor development and spread of plant diseases in general (Jones, 2016). It is, thus, necessary to put measures of control to avoid any disease introductions through unwarranted sharing of crops from one region to another.

The ToMV-Uganda isolate exhibited low genomic variability and its nucleotide substitutions were highly randomised. For instance, the $180 \mathrm{kDa}$ protein had the highest substitutions while the $17.5 \mathrm{kDa} \mathrm{CP}$ had the lowest. According to Pagán et al., 2010), the rate of evolution among tobamoviruses is generally low at $8 \times 10^{-5}$ to $1.3 \times 10^{-3}$ nucleotide substitution/site/year. This is so because most tobamoviruses tend to conserve most of their nucleotides for successful infection (Pfleger and Zeyen, 2008). Randomisation of nucleotide substitution could, thus, be due to functional or geographical adaptation. A comprehensive study, comparing different isolates from different agro ecological zones, is necessary to provide more insight into the structure of ToMV populations infecting tomato and other crops in Uganda.

\section{CONCLUSION}

This is the first study on full genome molecular characterisation of a ToMV isolate from Uganda as well as the Eastern and Central Africa regions. The isolate was notably, 98 to 100\% similar to ToMV strains from China, Japan and Germany implying it is a strain of the same virus species occurring in Asia and Europe. The study has documented low genomic variability and consequently nucleotide substitutions. This finding has an implication for stability of the pathogen if a new race emerges. Low variability at genomic level would lead to less resistance. This, therefore, means that other sources of resistances need to be deployed through introducing new variability (crossing, importing new sources of resistances from other areas). The information generated herein will help in further diagnostics and disease management. Further analysis of the evolutionary relationships of Tomato mosaic virus strains occurring within and outside Africa will add knowledge on viral migration and evolutionary dispersal of the species.

\section{ACKNOWLEDGEMENT}

This research was funded by the United States Agency for International Development through the African Food Security Initiative (AFSI) grant to the East African Site of the Integrated Pest Management Innovation Labs [formerly the Integrated Pest Management Collaborative Research Support Program (IPM/CRSP)] and the International Plant Diagnostics Network (IPDN).

\section{REFERENCES}

Aguilar, I., Sánchez, F., Martín, A., MartínezHerrera, D. and Ponz, F. 1996. Nucleotide sequence of Chinese rape mosaic virus (oilseed rape mosaic virus), a crucifer tobamovirus infectious on Arabidopsis thaliana. Plant Molecular Biology 30:191197.

Arinaitwe, W. 2013. Incidence, symptom severity and distribution of tomato viral diseases in Uganda. M.Sc. Thesis, Makerere University. Kampala, Uganda. 70pp.

Biosca, E.G., Marco-Noales, E., Ordax, M., and Lopez. M.M. 2006. Long-term starvation-survival of Erwinia amylovora in sterile irrigation water. Acta Horticulturae 704: 107-112. 
Goelet, P., Lomonossoff, G.P., Butler, P.J.G., Akam, M.E., Gait, M.J. and Karn, J. 1982. Nucleotide sequence of Tobacco mosaic virus RNA. Proceedings of National Academy of. Science, USA 79: 5818-5822

Hansen, A.J. 1990. Report on consultancy on fruit trees and vegetables virology. UGA/ 87/003, FAO / UNDP. 43pp.

Jones, R.A.C. 2016. Future scenarios for plant virus pathogens as climate change progresses. Advances in Virus Research 95: $87-147$.

Lanter, J.M., McGuire, J.M. and Goode, M.J. 1982. Persistence of tomato mosaic virus in tomato debris and soil under field conditions. Plant Disease 66: 552-555

Lartey, R.T., Voss, T.C. and Melcher, U. 1996. Tobamovirus evolution: Gene overlaps, recombination, and taxonomic implications.
Molecular Biology Evolution 13:13271338.

Letschert, B., Adam, G., Lesemann, D.E, Willingmann, P. and Heinze, C. 2002. Detection and differentiation of serologically cross-reacting tobamoviruses of economic importance by RT-PCR and RTPCR- RFLP. Journal of Virological Methods 106:1-10.

Pagan, I., Firth, C. and Holmes, E.C. 2010. Phylogenetic analysis reveals rapid evolutionary dynamics in the plant RNA virus genus Tobamovirus. Journal of Molecular Evolution 71:298-307.

Ssekyewa, C. 2006. Incidence, Distribution and characteristics of major tomato leaf curl and mosaic virus diseases in Uganda. PhD thesis. Faculty of Bioscience Engineering, Ghent University, Ghent, Belgium. 233pp. 